main available only on exchange terms from a number of organizations scattered throughout the U.S.S.R. These exchanges are being developed as rapidly as possible. The main difficulty is to track down what is available and the addresses of producing organizations. The Unit will welcome any assistance in this task. Although the bulk of the Russian literature held is very recent, a service for it is being started. Further information can be obtained from the D.S.I.R. Lending Library Unit, 20 Chester Terrace, London, N.W.1.

\section{Scientific Translation and Languages}

A Report on "Scientific and Technical Translating and other Aspects of the Language Problem" (pp. 282 : Paris : Unesco, 1957) is the result of collaboration between the Secretariat and 219 persons from twenty-one countries, arising out of a resolution adopted at the seventh and eighth sessions of the Organization's General Conference in 1952 and 1954. This authorized the Director-General "to advise and encourage international organizations concerned with the development and improvement of scientific documentation, standardization of terminology, compilation of multilingual dictionaries, and the improvement of terminology". In the first chapter the magnitude of the problem is appraised and the qualitative aspects of translating are reviewed in the second. Two chapters on methods and organizations for translation and distribution follow and the problems of increasing scientists' knowledge of languages are then discussed. In this connexion there is appended to the report a useful bibliography of books for technical language study. The concluding two chapters deal with the possible use of languages which are internationally understood so as to minimize the need for translation, and with terminology and lexicography. The latter is in continuation of activities initiated in response to a recommendation of the International Conference on Science Abstracting in 1949. There is a general bibliography and also a list of proposals regarding which further expressions of opinion are invited. No decisions have yet been taken by Unesco upon these proposals and the report is to be regarded as a statement of progress put forward in the hope that proposals may be reached for positive action which could be undertaken if funds permit.

Some interesting figures are given in the first chapter of the report. From a random sample of 1,000 scientific periodicals, English appears to be the dominant language, accounting for 436, compared with 144 in German, 126 in French, 53 in Spanish, 93 in other Latin script, 81 in Russian and other Cyrillic, and 36 in Italian. Except in geology and mining, meteorology and palæontology, in which English accounted for only 25 out of 96 , this proportion held in all the main subject groups : for example, 32 out of 88 for pure and applied sciences in general; 24 out of 59 in mathematics and physics ; 23 out of 54 in pure and applied chemistry; 43 out of 100 in biology, bacteriology, etc. ; 78 out of 193 in medicine, pharmacy, dentistry; 65 out of 122 in engineering, transport, building, architecture; 9 I out of 185 in agriculture, forestry, fisheries; and 25 out of 48 in leather, plastics, rubber, textiles, etc. It is also estimated that out of some $4,624,000$ scientists and technologists, 1,643,000 can read German, 361,000 Spanish, 2,650,000 English, 1,206,000 French, and 1,131,000 Russian.

\section{Acta Virologica}

AN increasing effort is being made to render the Iron Curtain permeable to scientific knowledge. Much of interest is reported in the first number of Acta Virologica (Vol. 1, No. 1 (January-March, 1957). Pp. 64. English edition. Annual subscription $30 \mathrm{~K}$ čs. Orders to ARTIA, $30 \mathrm{Ve}$ smečkách, Prague). This journal is edited by D. Blaškovič of Bratislava in Czechoslovakia with A. A. Smorodintseff of Leningrad as sub-editor, and is published quarterly under the auspices of the Czechoslovak Academy of Sciences. It is to appear in two editions, in English and Russian respectively. The articles in the first number, which come from Bratislava (three), Leningrad (two), Warsaw, Peking and Sofia (one each), represent serious contributions to virology. The English is good, as are the illustrations, some of which are in colour, and the journal is well produced. If the standard is maintained, Acta Virologica should prove a very worthwhile venture, of much benefit to the subject.

\section{The Woollen Industry}

Throvghout the world, the woollen industry has an incomparable record in its efforts to find more and more uses for this natural fibre. These efforts are matched by the exertions the industry has made to improve the wearing quality of the fibre and to find more people who wish to use it. All those concerned must be gratified with the results achieved. The review of the International Wool Secretariat and Wool Bureau Incorporated for 1956-57 shows that wool had a remarkable resurgence during the year, particularly in the United States; it is still the most popular clothing fibre throughout the world. The United Kingdom remains as the largest woolproducing country in Europe. The work of the education, publicity, trade promotion, economics, and science and technology branches of the International Wool Secretariat and Wool Bureau are described in the review, which is most attractively illustrated. Copies may be obtained from the International Wool Secretariat, 18-20 Regent Street, London, S.W.1, or from the Wool Bureau, 16 West 46th Street, New York 36.

\section{Food Additives}

THE use of food additives-with all their attendant dangers - is now so widespread that the World Health Organization and the Food and Agriculture Organization have felt it necessary to set up a joint expert committee to examine the position and advise on the measures needed to safeguard the health of the consumers. Its first report has recently been published (General Principles governing the Use of Food Additives. W.H.O. Tech. Rep. Ser. No. 129. Geneva, 1957. 1s. 9d.), dealing with the use and abuse of "non-nutritive substances added intentionally to food ... to improve its appearance, flavour, texture or storage properties". While allowing that such additives may, in certain circumstances, reduce the wastage of food or provide essential aids in food processing, it is clear that without close legal control their use may result in a substantial reduction in the nutritive value of common foods, they may disguise faulty processing and handling techniques, and they may expose the consumers to unknown risksnot only from the intake of substances abnormal in themselves but also from the further possibility that the combined effect of a number of additives in differ. 